\title{
Debate: Decolonising Fascist Studies
}

\author{
Liam Liburd \\ Durham University, Durham, United Kingdom \\ liam.liburd@durham.ac.uk \\ Paul Jackson | ORCID: 0000-0003-4733-5679 \\ University of Northampton, Northampton, United Kingdom \\ paul.jackson@northampton.ac.uk
}

\begin{abstract}
The drive to decolonise is of central importance to the study of fascism, which after all was and remains a politics rooted in specific conceptions of colonialism and race. In this article, we have invited both leading academics and early career scholars to reflect on how we might 'decolonise' fascist studies. Their comments approach fascism in a range of contexts, and offer reflections on how to frame future research questions, approach methodological issues, and consider how fascism studies might develop a more overt and clear stance on the problems posed by decolonising the subject area more broadly. It is hoped that these commentaries will enrich the field of fascist studies and, in turn, do more to relate it to the work of scholars in other relevant areas of study, particularly those working on critical theories of race and racism. Contributors to this debate are: Leslie James, Raul Carstocea, Daniel Hedinger, Liam J. Liburd, Cathy Bergin, Benjamin Bland, Evan Smith, Jonathan Hyslop, Benjamin Zachariah, and Caroline Campbell.
\end{abstract}

\section{Keywords}

decolonisation - fascist studies 
The editors of the essay collection Decolonising the University defined 'decolonisation' as:

a way of thinking about the world which takes colonialism, empire and racism as its empirical and discursive objects of study; it re-situates these phenomena as key shaping forces of the contemporary world, in a context where their role has been systematically effaced from view. ${ }^{1}$

To 'decolonise' is not just to think differently but to act differently, not simply theory but practice or, more accurately, praxis. The term was popularised by the struggles of student activists at the University of Cape Town (UCT) in South Africa who, in 2015, sought to remove the statue of Cecil Rhodes from their campus as a first step in a challenge to UCT's institutional culture and to the active legacy of South Africa's history of dispossession, oppression and exploitation of black people. History — in this case that of colonialism and apartheid — and the way that it informs and shapes the present, was at the centre of their campaign. Their demands focused on the university as an institution of learning with demands for curriculum reform but also as an employer with demands around funding, financial support and wages. If knowledge is power, they asked, what did it mean that UCT maintained one of the most prolific white supremacists in history as the symbol of that power? How had it shaped institutional culture, especially its treatment of staff members and students of colour? How had this presence conditioned what was taught and the way it was taught?

The questions posed by the Rhodes Must Fall Movement were by no means relevant only to UCT or to South Africa. A similar campaign sprung up at the University of Oxford mounting opposition to the statue of Cecil Rhodes atop Oriel College as part of a broader campaign against a lack of diversity in terms of staff, students and curricula. In turn, these campaigns were related to other student activism against historic racial injustice in the United States of America and against caste prejudice at some Indian universities. They have focused critical attention on systems of higher education and academic knowledge, pointing to the ways universities were at the centre of imperial projects, and played a crucial role in the normalisation of ideas of racial hierarchy. The international reaction to the murder of George Floyd in the summer of 2020, cast new light on the physical and ideological legacies of racism and colonialism

1 Gurminder K. Bhambra, Dalia Gebrial and Kerem Nişancioğlu, 'Introduction: Decolonising the University?' in Decolonising the University, eds. Gurminder K. Bhambra, Dalia Gebrial and Kerem Nişancıoğlu (London: Pluto, 2018), 2; Gurminder K. Bhambra, Kerem Nişancıoğlu and Dalia Gebrial, 'Decolonising the University in 2020,' Identities 27, no. 4 (2020): 509-516. 
across the world. From Birmingham, Alabama to Bristol, England, and from Montreal to Belgium, statues of slavers, settlers, and imperialist statesmen are being toppled, defaced or destroyed, and not just on university campuses. But just as it was for the Rhodes Must Fall Movement in South Africa, this was never solely about statues. The term 'decolonisation' is now on the lips of everyone from students to university administrators to government ministers, and is applied to the desire to reshape everything from universities to individual academic disciplines such as history and others, to museums and a range of other institutions. Used, misused and abused, at the root of term are aspirations not only to dismantle white supremacist or colonial ways of viewing the world, but also to build fairer, more equal and democratic societies.

The drive to decolonise is of central importance to the study of fascism, which after all was and remains a politics rooted in specific conceptions of colonialism and race. In this debate article, we have invited both leading academics and early career scholars to reflect on how we might 'decolonise' fascist studies and begin thinking about fascism in ways as described above. Some of our contributors come from within the field of fascist studies, others from outside of it and work instead on the broader histories of empire, racism and anti-racism. Their comments approach fascism in a range of contexts, and offer reflections on how to frame future research questions, approach methodological issues, and consider how fascism studies might develop a more overt and clear stance on the issues decolonising the subject area more broadly. In doing so, we hope to open up the field to new critical perspectives. It is hoped that these commentaries will enrich the field of fascist studies and, in turn, do more to relate it to the work of scholars in other relevant areas of study, particularly those working on critical theories of race and racism.

\section{Leslie James, Senior Lecturer in Global History, Queen Mary University of London, UK}

Let me begin with what I hope is a generative provocation. Fascism was not only an external threat to colonised societies but also internal to them. For me, and in my own work, testing and elaborating this point is one of the key tasks for a richer understanding of fascism's histories.

There are several layers to approaching fascism as internal to colonised societies. Existing scholarship has provided a skeleton for this approach - most of which I cannot do justice to here-but there is much more detail to unearth. We know, for example, that the Indian Marxist M.N. Roy wrote, from a prison cell in British India in the 1930s, of an Indian form of fascism that was pri- 
marily cultural and emerged from civilisational ideals. He distinguished discrete Italian, German, and Indian fascisms. ${ }^{2}$ Jamaica's Marcus Garvey criticised Nazi antisemitism but also claimed that his organisation, the Universal Negro Improvement Association, were the first fascists. Garvey and the movement that bears his name is far too nuanced to be labelled fascist—indeed, Garvey's statements produced a vocal critical response from many of his followers. ${ }^{3}$ The point is that one layer of enquiry can fill in how fascism's emphasis on pride in- and work for-your 'nation' made perfect sense to some who sought to extricate themselves from racism and colonial rule. ${ }^{4}$ Second, for many observers in the 193 os fascist and colonialist attitudes and practices looked very similar: was fascism, as Aimé Cesaire succinctly put it in the 1950s, 'colonialist procedures applied to Europe'? ${ }^{5}$ My current research shows that, in British West Africa and the Caribbean, workers and educated elite alike debated whether colonial rule was fascist - the nature of fascism was a question central to their own context. Finally, there are of course histories of fascist organisations and parties that formed in colonial territories. We can continue to elaborate their enrolment, ideas, and impact on local politics.

Why does approaching fascism as internal to colonised societies matter? What might it do for fascist studies? First, it cuts to the heart of the overall trend that sees fascism as spreading outward from Europe. Fascism studies has debated, for decades now, the veracity of whether fascism should be understood in a specific European originary form. This is intrinsically tied to the question of the nature and definition of fascism: is fascism a set of separate cases of political practice? An ideology? A form of political behaviour? It seems to me that the current models and frameworks have proved insufficient to close this debate because it has never fully been tested globally. It needs to be tested more fully, and indeed more historically accurately, by analysing fascist ideas, associations and practices in colonised societies. This angle will almost certainly deepen our understanding of the fundamental questions scholars of fascism work from. It can form one part of interrogating fascism outside Europe.

2 M.N. Roy, 'The Philosophy of Fascism,' in Selected Works of M.N. Roy, vol. IV, ed. Sibnarayan Ray (Delhi: Oxford University Press India, 1997). For M.N. Roy see Kris Manjapra, M.N. Roy:Marxism and Colonial Cosmopolitanism (Delhi: Routledge India, 2010). For recent scholarship on fascism in India see the works of Benjamin Zachariah, Ali Raza and Franziska Roy.

3 Robert Hill, 'Introduction,' in The Marcus Garvey and Universal Negro Improvement Association Papers: Africa for the Africans, 1923-1945. Volume X, ed. Robert A. Hill et al. (Berkeley: University of California Press, 2006), ciii.

4 David Motadel, 'The Global Authoritarian Moment and the Revolt against Empire,' American Historical Review 124, no. 3 (2019): 843-877.

5 Aimé Césaire, Discourse on Colonialism (New York: Monthly Review Press, 1972 [1955]), 36. 
Second, this approach has implications for the writing of twentieth century history more broadly and the thrust of mid-century decolonisation specifically. The global war against fascism is assumed to have quickened the pace of decolonisation around the world because of colonial contributions to the Allied war effort and the war's fundamental claim to self-determination. This interpretation does not appreciate how anti-colonial movements staked their claims on anti-fascist lines both before 1939 and after 1945. In a forthcoming article, I argue that understanding anti-colonial anti-fascism before 1939 explains the remarkable staying power of anti-fascism within anti-colonial and anti-racist movements in the second half of the twentieth century. ${ }^{6}$

The work to decolonise knowledge, disciplines, and institutions is not solely about representation. It is also about applying a stronger range of epistemologies that will test current assumptions and arrive at new, fuller, and more specific conclusions. Yes, viewing fascism as within the histories of colonised societies - rather than a force that acted upon them-restores primary agency to colonised peoples. It also, fundamentally, demands attention to how people have understood the nature of fascism itself. Decolonising fascist studies cannot solely be about expanding the geographical focus beyond Europe nor about including non-European actors in the canon. It should also bring a set of questions that will help interpret fascism in new ways. Over time, this might also help us return to older fundamentals in the rich expanse of scholarly exploration.

\section{Raul Carstocea, Lecturer in Twentieth-Century European History, Maynooth University, Ireland}

Unlike recent calls to decolonise the curriculum, the notion of decolonising fascism studies may appear outright paradoxical. After all, in this case, notions of being more inclusive and listening to both sides of the story, when one of those sides is seen as the epitome of opposition to any form of cultural pluralism, may appear nonsensical. Yet, with the stakes being increasingly political and not just scholarly, this is precisely what we need to do, in order to understand fascism's global appeal in the interwar period and its possible return, in a mutated form, in the present.

6 Leslie James, 'The Face of Fascism,' forthcoming in American Historical Review (September 2022). 
As a first step, fascism needs to be spatially unmoored from the two regimes in interwar Europe, Fascist Italy and Nazi Germany. Here, recent literature is well underway to reading fascism as a transnational phenomenon, with an ongoing 'global turn' representing another promising development. Yet too often such studies still take the two European regimes as benchmarks or even models, with 'variations' accounted for against this 'standard' of what fascism really was. The result is a Eurocentric and regime-centric approach that misses out on the diversity of fascisms, a direct consequence of their being shaped everywhere by their native character, on account of the ideology's ultra-nationalism. Along these lines, fascisms on Europe's periphery or outside the continent might be treated less as aberrations or imperfect adaptations of a (Western) European model, and more as local variants of a global phenomenon, certainly neither 'minor' nor 'peripheral' to their victims. The political implications of this are significant, as regime-centric approaches allow dismissing (in some cases significant) fascist movements that failed to take power and delivering a comforting narrative of stable democracies that were able to withstand the fascist temptation.

Secondly, and already more problematically, fascism needs to be temporally untethered from its neat interwar time capsule, with its applicability in the present discussed more seriously. Beyond the notable differences in historical context which necessarily mean its twenty-first century manifestations will be markedly different from the interwar ones, more attention to fascism as an ideology and a concept might allow us to capture both continuities and transformations. With Julia Adeney Thomas and Geoff Eley, we might then read fascism as a 'portable concept,' ${ }^{7}$ intentionally adapted to both the different character of the present crises it responds to and to the notoriety of its interwar counterpart. Certain recent developments along these lines can be encountered, mostly for the case of Donald Trump's presidency in the United States of America, but much more remains to be done to explore the closing gap between an increasingly global neo-fascist network of movements and actors with explicitly violent aims and the equally global shift to the right in mainstream politics, as well as their potential common ground.

This brings me squarely to my third and last consideration, the most problematic but perhaps precisely for that reason the most important, i.e., the need to move away from a normative, moral and moralising, interpretation of fas-

7 Julia Adeney Thomas, 'Introduction: A Portable Concept of Fascism,' in Visualizing Fascism: The Twentieth-Century Rise of the Global Right, eds. Julia Adeney Thomas and Geoff Eley (Durham NC: Duke University Press, 2020), 1-20; Geoff Eley, 'What is Fascism and Where Does it Come From?' History Workshop Journal 91, no. 1 (2021): 1-28. 
cism, one that naturalises a specific political position (liberalism) as allegedly neutral ground for analysis. In so doing, it condemns fascism before attempting to understand it in earnest, and thus fails to grasp its mass popular appeal in the interwar period, before the horrors of the Second World War fully exposed its genocidal character. It also fails to take stock of the fact that fascism was intended from the outset as an insurgency against the Western hegemonic narrative of liberal progress, yet one that was synthetically grounded in its racist and colonial tenets. Paradoxically perhaps, decolonising fascism studies might thus translate into 'colonialising' fascism, i.e., revealing its long-term filiations with racial hierarchies, colonial practices and forms of violence, while mindful of the ways in which fascist notions of empire were profoundly distinct from liberal ones.

This might be a fine line to tread, with charges of 'whitewashing' fascism easily imaginable, but I believe that respectable scholars of fascism studies are (hopefully) beyond suspicion in this regard. Such an endeavour is central to decolonising fascism studies, however, as 'taking fascist values seriously' is something the field has claimed more often than practiced, at least insofar as the reception of the ideology at the grassroots level, among the 'masses' that gave fascism its mass character, is concerned. To clarify, taking fascism seriously does not entail lending any credence to its arguments and tropes as talking points for the present, but understanding how and why they were not merely intelligible, but even appealing, i.e., reconstructing both the logic of fascist argumentation and that of its reception, precisely as historically-situated phenomena with an inherent diversity. A shift from a quasi-exclusive focus on elites and toward a more inclusive, social history of rank-and-file fascists, sensitive also to a more nuanced view of gender relations, would go a long way to further pluralise fascism studies, not only geographically but by including perspectives 'from below'. Moreover, accepting that and understanding why people found in fascism an appealing solution to a sense of generalised crisis might be key to preventing that they do so again.

\section{Daniel Hedinger, Lecturer (PD) in Modern History, Ludwig Maximilian University of Munich, Germany}

Fascism has, and often still is, understood as the white man's burden. This holds true for both the historical phenomenon as well as for the research field. As a historical phenomenon, it is easy to see why: most of the early fascist movements popped up in Europe. And most of them consisted of a pack of ultranationalist racists, who put not only their nation but also the destiny of white 
Europeans first. During the interwar years, through imperial expansion and colonial radicalisation, fascism turned out to be first and foremost something Europeans did to others- to people fascists defined as non-European or nonwhite. In this sense, too, fascism was indeed a white man's burden. Little wonder, then, that, in much of the literature, the main cast of fascists have always been white. The rest were belated imitators, mere pretenders, or something else entirely. For Stanley Payne for example, 'generic fascism' was 'a uniquely European phenomenon'. ${ }^{8}$ Consequently, non-European forms of fascism (and, by the way, also anti-fascism) have been widely overlooked. Hence, it may be of little surprise that the field of fascist studies itself still is very much 'white', too-researched and taught at Western universities and mainly by white men.

This limited conception of fascism means that the global dynamics of fascism are still not well understood. Fascism did not emerge in a Europe isolated and detached from the world. Take, for example, fascist imperialism, which after 1919 was first and foremost a jealous reaction to the existence of the colonial empires held by other great powers. In this context, fascists dreamed of overcoming their nation's own lack of colonies or (semi-) colonial status through imperial expansion. Postcolonial studies have shown the impossibility of writing national histories without including the histories and insights of the colonised; insights and histories which should be incorporated into fascist studies. However, there are deeper issues with a 'Europe-first-model': it makes European movements and regimes not the object but the standard of comparison. This, in turn, reinforces the subordination of the rest to the so-called 'West'. As fascists aimed above all at a new, hierarchical, and racist world order, the inclusion of postcolonial theory, which has scrutinised Eurocentrism and white supremacy as a byproduct of colonialism for decades, seems even more a necessity.

So how can we overcome this white man's burden? I believe decolonising fascism implies, first and foremost, three things. First, we have to decolonise the categories and models, as they derive from European movements and regimes (usually the German or/and Italian cases). Often, such ideal-typical fascist minimums or stage models do not fit well to non-European cases. For example, Japan went from empire to fascism during the interwar years, whereas Italy or Germany went the other way around, from internal fascist revolution to imperial expansion. Therefore, models that emphasize the foundation of a party, internal civil war, and then a successful take-over of power as the first steps exclude the Japanese case. Thus, we need to decenter the European

8 Stanley G. Payne, Fascism: Comparison and Definition (Madison: University of Wisconsin Press, 1980), 175 . 
experience by introducing more flexible categories, concepts, and chronologies concerning global fascism. What then becomes visible are 'glocal' forms of fascism and complex processes of mutual radicalisation on a global scale, at least for the quarter century after 1919. Secondly, our perspectives can be decolonised by systematically including non-European perspectives. However, in this context, what we need is less a transnational approach, which would focus on interactions between European nation-states, than a transimperial focus, which stresses connectivity, cooperation as well as competition between empires. Such an approach helps to better understand fascism as a global phenomenon of the interwar years by emphasizing its emergence's colonial context and imperial nexus. Thirdly and finally, decolonising the field of fascist studies implies something much broader and profound than the inclusion of a wider range of examples. We must incorporate and include non-European voices, institutions, and theoretical perspectives, opening up the field to participants with different disciplinary backgrounds and experiences. This is all the more important as the Eurocentrism of both the research focus as well as the research field is strongly interlinked and mutually reinforcing. Therefore, one cannot decolonise one without the other.

\section{Liam J. Liburd, Assistant Professor in Black British History, Durham University, UK}

When we talk about 'decolonising' fascist studies, it is not so much a matter of how we might 'begin' thinking about fascism in a way that takes 'colonialism, empire and racism as ... key shaping forces of the contemporary world'9 but about rediscovering the work of those thinkers who began doing this decades ago. From the 193os, a number of Black thinkers conceptualised European fascism in terms of its affinities to colonialism. For activists and intellectuals of colour throughout the British Empire (but also in other European empires and in the United States), fascism was 'no more an historical aberration than colonialism, the slave trade, and slavery.'10

What I'd like to suggest is that one way in which we might 'decolonise' fascist studies is to recover and to take seriously the polemical analyses of Black thinkers and activists—including W.E.B. Du Bois, George Padmore, and Aimé

\footnotetext{
$9 \quad$ Cedric J. Robinson, 'Fascism and the Responses of Black Radical Theorists,' in Cedric J. Robinson: On Racial Capitalism, Black Internationalism and Cultures of Resistance, ed. H.L.T. Quan (London: Pluto Press, 2018), 152. Ibid.
} 
Césaire-about the relationship between colonialism and fascism. Doing so entails a refusal to treat fascism as exceptional or as a species apart and to think about it in a 'joined-up' way, as these earlier thinkers did, analysing its connections with the broader history of racism and empire.

In terms of my own research on the British radical right such an approach illuminates the various different ways in which British fascists were, throughout the twentieth century shaped by British imperial ideology. The white supremacism of groups like Britain's first self-identifying fascist group, the British Fascisti, or Oswald Mosley's British Union of Fascists, or the lesserknown Imperial Fascist League cannot be accurately separated from the longer imperial history of white supremacism in the 'British world'. Radical right activists and ideologues drew deeply from this tradition, seeking to emulate the kind of white masculine ideal that was said to exist out in the Empire, the ideal set to verse by Kipling and taught to British youth by Baden-Powell. Even the more seemingly esoteric aspects of their ideology - their antisemitism or conspiracy-theorising, for instance-had colonial antecedents in theories about Jewish influence over imperial policy or in anxieties over anti-colonial plots.

Adopting this critical 'Black' perspective on the study of fascism involves remaining attentive not only to the ways in which British fascists were shaped by an earlier imperial politics of race but also how their presence, in turn, shaped that politics in the present. Much of the discussion about post-imperial racism focuses on Enoch Powell's influence on British racism. What this obscures is the earlier role played by organisations like Oswald Mosley's Union Movement, A.K. Chesterton's League of Empire Loyalists, and, especially, groups like the White Defence League and the National Labour Party (and the later merger of these two into the British National Party). These groups campaigned noisily against Commonwealth immigration from the 1950s in terms that explicitly referred to decolonising Africa, comparing white Britons to the white settlers in southern Africa. In doing so, they helped to inject a colonial conception of whiteness into domestic British politics in a way that laid the ground for Powell and the subsequent development of a post-imperial racism based around the idea of 'whites under siege'.

This approach-which we might call 'thinking black' about British fascism - offers us the opportunity to open the field up to insights of critical theorists from Stuart Hall, Paul Gilroy and more." Interrogating the 'white' in white supremacy offers academics, researchers and the students the means of

11 Rob Waters, Thinking Black: Britain, 1964-1985 (Oakland: University of California, 2019), 3. 
meaningfully refocusing the field on the urgent and relevant issues of the legacy of empire and the history of the politics of whiteness.

\section{Cathy Bergin, Principal Lecturer, University of Brighton, UK}

As early as 1923 the African American Socialist newspaper The Messenger argued that 'Fascism like Ku Kluxism is the white guard of plutocracy-two brokers of unspeakable terrorism. ${ }^{12}$ This cojoining of home-grown racialized terror and fascism was to dominate African American forms of anti-fascism throughout the twentieth Century. Moreover, for African American antifascism the normalisation of race hatred was embedded not just in the actions of avowed white supremacists, but in the supposedly 'colourblind' racism of the liberal state. It is a theory of fascism which, without a pause for breath, sees it not as the 'other' to liberal democracy but produced by liberal democracy's foundational exclusions.

Again and again in the 1930s, 1940s and late 196os African American activists and writers insist that it is not that fascism leads to racial genocide but rather that the condition of the African American, as a fanatically raced subject of the American State, leads to forms of fascism. This is particularly apparent in the mid-century where the Jim Crow south is cited as a form of 'domestic fascism'. Focusing less on an analytical categorisation of the South as fascist, the effect of this characterisation was to name fascism a particular threat to people of colour. It was also concurrently to see people of colour a particular threat to fascism. African Americans as both the primary object of persecution and the source of consistent and myriad forms of resistance were a potential vanguard against fascism and racism. As Langston Hughes insisted in his Spanish Civil war poetry: 'Fascists is Jim Crow peoples, honey / And here we shoot 'em down.'13

In the late 196os the Black Panthers again insisted that the repressive arm of the state targeted black communities to continue a system of racialized terror. In insisting that African Americans have long lived in an ultra-violent, democracy crushing, mass incarcerating and intractable system intent on black erasure, African American radicals troubled the spatial and temporal co-ordinates of traditional analysis of fascism. This speaks also to the work of diasporic Caribbean activists George Padmore and Aime Cesaire, in their insistence that fascism's routes were embedded in western colonialism and its mystifications.

12 'The Fascisti in America,' The Messenger, June 1923.

13 'Love Letter from Spain,' The Daily Worker, 23 January 1938. 
It is not the case that Black anti-fascism in the US collapsed racism into fascism or were simply mobilising the rhetorical power of the word in their naming of institutionalised racism. Rather African American activists who named elements of the state as 'fascist' were underlining how the thwarted dynamics of racialisation instantiated forms of terror. These forms of terror ensured that racialised subjects were prey to the anti-democratic and violent vagaries of the racial state. The African American claim on the word 'fascism' has insisted on the culpability of the state and its agents in the maintenance and reproduction of forms of white dominance which obliterate black lives and black life. This claim has re-emerged in a myriad of ways in the age of Black Lives Matter, it has long routes and roots in the black radical tradition.

\section{Benjamin Bland, Lecturer in Contemporary History, University of York, UK}

In the summer of 1969, the Black Panther Party organised the National Conference for a United Front Against Fascism. This unambiguously anti-fascist event-held over four days in Oakland, California—was a notable moment in the history of the African American liberation struggle. One of its central themes - the demand for communities to wrest control of policing away from the 'fascist pigs' — remains particularly pertinent today. This, and many other postwar anti-racist campaigns that attached the fascist epithet to their oppressors, are nowhere to be seen in the field of fascist studies. On the one hand, this is understandable. As someone whose current project deals largely with analogies drawn between fascism and various aspects of life in postwar Britain, I can attest that comparisons of this kind are frequently ahistorical and sometimes totally illogical. Crucially, however, that does not mean that they do not matter. After all, realistically speaking, it is these analogies — not scholarly endeavours - that have shaped popular understandings of fascism in the postwar world. In many cases - and I think the United Front Against Fascism is one of these - the word 'fascism' may not have a meaning that would fit most scholarly definitions of the term, but it is easily powerful enough to merit being taken seriously. Such examples present a challenge to fascist studies, but one that it is essential to meet head on if any decolonisation of the field is to take place. This is partly for the simple reason that there is a very long history of anti-racist and anti-colonial usage of the term 'fascism', and this history is populated by a far more diverse set of actors than works of fascist studies have generally focused on to date. More importantly still, the critiques of ostensibly 'anti-fascist' liberal democracies found within this history highlight the need for fascist studies 
to think more seriously about its relationship to anti-racist practice. Whilst it is true that fascist studies scholars have focused analytically on the ways in which fascists themselves have constructed 'race', this has rarely been accompanied by any direct challenge to the exceptionally powerful processes of racialisation that have occurred alongside, as well as through, fascism. Fascist studies needs to pay far more attention to the racialised logics and power structures that have played a central role both in enabling fascism and in linking it to wider patterns of prejudice, discrimination, and oppression.

Scholarship on fascism can-and should—play a role in critiquing and undermining these logics and structures, acting not just to undermine overt racism but also to disrupt the divisive constructions of 'race' that continue to dominate states and societies across the globe today. This unavoidably means moving away from a focus on what fascism is and was towards a recognition of the more diffuse ways in which fascism has been understood and discussed. The resulting world of analogy and comparison that is opened up may be difficult to navigate but, as Michael Rothberg has ably demonstrated in the field of Holocaust studies, it need not be obstructive. ${ }^{14}$ Crucially, as Priya Satia has recently argued, analogies between fascism and other phenomena (historical or otherwise) must not be thought about strictly in terms of normalisation or abnormalisation. Instead, we should think about what such comparisons may illuminate about historical connections and constructions that otherwise risk being obscured by popular narratives of exceptionalism and alterity..$^{15}$ For the decolonisation of fascist studies to take place, such a shift - encompassing a broader range of research agendas and approaches that consciously look beyond what is conventionally thought of as 'fascism' - seems an essential prerequisite.

\section{Evan Smith, Visiting Fellow, Flinders University, Australia}

In 1950, Aimé Césaire argued in Discourse on Colonialism that Nazism had 'applied to Europe colonialist procedures which until had been reserved exclusively' for people in the colonies of Africa and Asia. ${ }^{16}$ Historians have continu-

\footnotetext{
14 Michael Rothberg, Multidirectional Memory: Remembering the Holocaust in the Age of Decolonization (Stanford, CA: Stanford University Press, 2009).

15 Priya Satia, 'Fascism and Analogies - British and American, Past and Present,' LA Review of Books, March 16, 2021, https://lareviewofbooks.org/article/fascism-analogies-british-ame rican-past-present/, accessed November 12, 2021.

16 Aimé Césaire, Discourse on Colonialism (New York: Monthly Review Press, 2001), 36.
} 
ally debated the relationship between colonialism and fascism and whether Fascist Italy and Nazi Germany were attempting to replicate the imperialism of both countries from before the First World War. Looking at fascism in Britain, several scholars, such as Liam Liburd and Paul Stocker, have highlighted that the fascism of Oswald Mosley's British Union of Fascists, A.K. Chesterton's League of Empire Loyalists and the National Front was inspired by the British imperialism of the late Victorian and Edwardian eras and the desire for a 'greater Britain' was shared by the conservative mainstream to the fascist extreme right. ${ }^{17}$

Understanding how fascism was often informed by the politics of imperialism and colonialism is of particular importance for historians of fascism and the far right in the former settler colonies of North America, southern Africa and Australasia. Scholars, such as Patrick Wolfe and Lorenzo Veracini, have described settler colonialism as an invasive process involving the violent dispossession of the indigenous population, which shares an affinity with fascism's need for violent expansion and the 'cleansing' of populations for the desired nation. ${ }^{18}$ Robin D.G. Kelley and Cedric Robinson remind us that many Black activists in the interwar period saw 'fascism as a blood relative of slavery and imperialism. ${ }^{19}$ While staunchly anti-fascist, the Communist Party of South Africa noted in the early years of the Second World War that non-Europeans in the Union were not wholly convinced that fascism was much different to the racial hierarchy that existed in South Africa at the time. ${ }^{20}$

After the Second World War, the far right across the Anglophone world expressed rising concern about the decolonisation process and the Cold War between capitalism and communism, viewing the West as susceptible to a loss of power due to geopolitical changes abroad, alongside immigration and pushes for civil rights for minorities in the domestic sphere. ${ }^{21}$ Fascism and far-

17 Liam J. Liburd, 'Beyond the Pale: Whiteness, Masculinity and Empire in the British Union of Fascists, 1932-1940,' Fascism 7, no. 2 (2018): 275-296, https://doi.org/10.1163/22116257 -o0702006; Paul Stocker, Lost Imperium: Far Right Visions of the British Empire, c. 1920-1980 (London: Routledge, 2021).

18 Patrick Wolfe, Settler Colonialism and the Transformation of Anthropology (London: Cassell, 1999); Lorenzo Veracini, Settler Colonialism: A Theoretical Overview (Houndmills: Palgrave Macmillan, 2010).

19 Robin D.G. Kelley, 'A Poetics of Anticolonialism,' in Aimé Césaire, Discourse on Colonialism (New York: Monthly Review Press, 2001), 20.

20 Evan Smith, 'Against Fascism, for Racial Equality: Communists, Anti-Racism and the Road to the Second World War in Australia, South Africa and the United States,' Labor History 58 , no. 5 (2017): 685 .

21 See the essays in Daniel Geary, Camilla Schofield and Jennifer Sutton, eds., Global White Nationalism: From Apartheid to Trump (Manchester: Manchester University Press, 2020). 
right politics were viewed as a means to return to the status quo of a previous era (most likely the turn of the twentieth century). For example, in Australia, the far right and neo-Nazi groups that existed in the postwar period demanded that the 'White Australia Policy' be maintained (and returned to the strict policies that were in place before 1939) and after it was abolished in 1975, other groups called for it to be reinstated. The Indigenous population were to be kept away from the cities and places of white settlement. The Australian 'bush' spirit of the late colonial and Federation eras was portrayed as being undermined by modernity and Australia's colonial past was celebrated. ${ }^{22}$

Some of the Anglophile far right, such as the League of Rights groups that spread from Australia to Britain, Canada and New Zealand or the National Front inspired groups in Australia, New Zealand and South Africa, emphasised the previous network of white Dominions across the British Empire. The 'white man's world' of the British Empire was venerated by the far right as the traditional international order that had been undermined in the postwar period. These groups called for apartheid South Africa and Rhodesia to be brought into a renewed British Commonwealth of the white Dominions, with these states under white minority rule championed as bulwarks against communism and multi-racial democracy.

As much as the British far right, the far right in Australia, New Zealand and Canada were shaped by the settler colonial origins of these countries and their political programme has often sought to return to the old imperial order. An understanding of fascism in the Anglophone world cannot be fully comprehended without recognizing the influence of imperialism and settler colonialism.

\section{Jonathan Hyslop, Professor of Sociology and African Studies, Colgate University, USA}

In its strongest formulations, the idea of 'decoloniality' might actually lead one to question the very distinction between fascism and colonialism in the Southern African context. Decolonial thought would stress the undoubted reality that in the colonial era, subjects of all southern African regimes, whether settler-controlled or metropolitan-centred, led lives constrained by racial struc-

22 Evan Smith, 'White Australia Alone? The International Links of the Australian Far Right in the Cold War Era,' in Global White Nationalism: From Apartheid to Trump, eds. Daniel Geary, Camilla Schofield and Jennifer Sutton (Manchester: Manchester University Press, 2020), 231-261. 
tures and ideologies and the accompanying denial of democratic rights, high levels of state violence and extremely coercive labour practices (and that this history has long-lasting legacies). This emphasis would point to the conclusion that there was no significant difference between overtly fascist colonial governments (such as Portugal in Angola and Mozambique) and those which claimed to align with democratic values (Britain in Northern Rhodesia for instance). In both cases the experience of the colonised was, it could be argued from this perspective, much the same. In South Africa, such a view actually has a precedent in the Second World War politics of an important Black leftist group, the NonEuropean Unity Movement. The NEUM opposed the pro-British war effort of the government of Prime Minister Jan Smuts, arguing that his regime was itself fascist. They adopted a rhetoric which portrayed themselves as analogous to the European resistance, for instance referring to Black participants in state structures as 'Quislings'. Black people, in this view, had nothing to gain from an Allied victory, as South African segregationists were indistinguishable from Nazis.

However, there is also a strong Black intellectual history in the region, in which opposition to fascism is a significant theme. Within South Africa, at the same time as the NEUM was emerging, the leadership of the main African nationalist organisation, the ANC, supported the war effort, using the rhetoric of the Atlantic Charter and Roosevelt's Four Freedoms. It is true that they thus hoped to bring leverage to bear on the Allies to impose a liberalisation of racial policies on Smuts. But ANC leaders like Dr A.B. Xuma believed that their ends would best served by an Allied triumph than by the success of Hitler and his local allies in the radical wing of Afrikaner nationalism. The distinction between fascism and other forms of rule was seen by them as being a weighty one. Moreover, during the era of guerilla war against the Portuguese in Mozambique and Angola, Ian Smith's government in Rhodesia and the South African apartheid order, both the insurgent movements and their allies abroad were often anxious to portray their opponents as 'fascist'. This was rhetorically useful, as a tactic of delegitimisation, but also (although often inconsistently) used as a point of departure for political analysis. There is thus a serious history of southern African Black intellectual engagement with the topic of fascism, and a closer look at that might be one useful way in which thinking about fascism from a decolonial perspective could be useful.

But, there are broader issues to which the decolonial approach might also usefully point us. One potential application is to insist that the experience of southern Africa needs to be given greater weight in Europe-focused studies of fascism. There is considerable debate on whether the Portuguese Estado Novo (1934-1974) was 'technically' fascist, but it is indisputable that it belonged to 
the family of prewar European authoritarian regimes. Its (NATO-backed) colonial wars in Angola and Mozambique from 196o to 1974 were major military and political struggles. Yet this enormous conflict has not sufficiently registered in the mainstream of European historiography. A decolonial perspective might suggest that this marginalisation reflects a reluctance to integrate the colonial world into historical thought about fascism. Similarly, Nazi overseas operations in the 'global South' have seldom been taken seriously as part of the main story of German Fascism. During the 1930s Nazis ran a vast international organisational operation. This included powerful Nazi movements amongst the wealthy German community in South African-ruled Namibia and support to small but vociferous fascist movements in South Africa. During the Second World War, a mass Afrikaner fascist movement, the Ossewa Brandwag, emerged in South Africa, which had strong clandestine links to Nazi intelligence and carried out sabotage operations. Without exaggerating their significance, a lot more could be done to relate these developments to events within the Reich and in the course of the Second World War. The question of whether they were more significant in the history of Nazism and the world conflict than has generally been allowed, might at least be a useful one to ask. ${ }^{23}$

\section{Benjamin Zachariah, Senior Research Fellow, University of Trier, Germany}

An international and comparative approach to fascism is beset by the difficulty of transcending specialisms and regional or national exceptionalisms, dominated by histories of Italy and Germany. There is also a tension among legalistic, historical (retrospective) and activist antifascist approaches. Legalistic delimitations of fascism emerged in the context of the end of the Second World War, where a central concern was to find grounds to prosecute members of fascist regimes. These were necessarily narrow so as to avoid bringing too many people within their ambit, and were out of joint with contemporary antifascists' understandings of and debates about the nature of fascism, which sought to understand the appeal of fascist ideas and the ability to gener-

23 For more on fascism in South Africa see: Patrick Furlong, Between Crown and Swastika: The Impact the Radical Right on Afrikaner Nationalism in the Fascist Era (Hanover NH: Wesleyan University Press, 1991), Christoph Marx, Oxwagon Sentinel: Radical Afrikaner Nationalism and the History of the Ossewabrandwag (Münster: Lit Verlag, 20o9), and Milton Shain, A Perfect Storm:Antisemitism in South Africa 1930-1948 (Johannesburg:Jonathan Ball, 2015). 
ate mass movements, and was therefore interested in a continuum rather than a crucial distinction dividing fascists from non-fascists. Activist and legalistic approaches continue to remain opposed to one another in spirit. Historians have also tended to restrict their definitions of fascism because of fears of 'concept inflation. ${ }^{24}$ In addition, there is a trend towards pinning fascism down as a phenomenon 'in its own times', ${ }^{25}$ which then requires the prefix 'neo-' for later versions, and relies strongly on conceptions of an 'original' (ideal-typically defined, and usually situated in Europe) and a 'copy', imperfect and therefore not the 'real thing.' 6

It is vital, therefore, not to lose sight of connections. My research deals with Indian variants of fascism; given that the public debates were internationally connected, fascism 'outside Europe' 27 and inside it is a distinction that must be avoided. Equally, a somewhat simplistic tendency towards 'decolonising' the study of fascism, often based on stray (and polemical) remarks by Aimé Césaire or Frantz Fanon, sometimes makes a similarly unhelpful separation of colonial and 'European' experiences ${ }^{28}$ (but then what role can we attribute to North Africans in the Spanish Civil War, for instance? ${ }^{29}$ _ and Fanon, as a Marxist, would have been aware of the equivalence stated (for instance by the Communist Party of India) between colonialism abroad and fascism at 'home' as parallel manifestations of capitalism, ${ }^{30}$ which had to have played a role in his formulation, if not Césaire's: Nazism produces the violence at the heart of 'civilized' Europe which is usually seen in colonial violence against (what to Europeans are) distant 'savages'.31 This view, when detached from the larger, and Marxian, context produces a lazy relativism or moral comparison of colonialism and fascism that produces for the conceptualisation of fascism what we might call a 'concept deflation'.

24 See for instance Ian Kershaw, 'Hitler and the Uniqueness of Nazism,' Journal of Contemporary History 39, no. 2 (2004): 239-254.

25 That was the phrase used by Ernst Nolte, Der Faschismus in seiner Epoche: Die Action française, der italienische Faschismus, der Nationalsozialismus (Munich: R Piper Verlag, 1963).

26 Benjamin Zachariah, 'Moving Ideas and How to Catch Them,' in After the Last Post: The Lives of Indian Historiography (Berlin and Boston: De Gruyter, 2019), 129-148.

27 Stein Ugelvik Larsen, ed., Fascism outside Europe: The European Impulse against Domestic Conditions in the Diffusion of Global Fascism (Boulder, Colorado: Social Science Monographs, 2001).

28 Frantz Fanon, The Wretched of the Earth (New York: Grove Press, 1963 [1961]), 90-91, 101, 172; see also Césaire, Discourse on Colonialism (1972 [1950]), 14.

29 See for instance Ali Al Tuma, 'Franco's Moroccans,' Round Table Article, Contemporary European History 29 (2020): 282-284.

$30 \quad$ Benjamin Zachariah, Nehru (London: Routledge, 2004), 80, 107.

31 See also Frantz Fanon, Black Skin, White Masks (New York: Grove Press, 1968), 115. 
Even within Europe, there has been a tendency to see a core and a periphery and to hierarchize European fascisms in terms of greater and lesser versions: Italian and German (and sometimes Spanish) as against Hungarian or Romanian fascism. ${ }^{32}$ But engagements with fascism were international, ${ }^{33}$ (fascism was one of the dominant ideologies of the first half of the twentieth century) and fascism was debated in terms of variations that were relevant to the 'character' of particular countries. ${ }^{34} \mathrm{~A}$ cursory glance at a primary source from fascism's 'own times' would make it clear that contemporaries did not see fascism as contained within Europe, and recognized it as a global phenomenon with different potential for realisation in different locations.

Fascists themselves sought to communicate and work with each other, ${ }^{35}$ whether within the (short-lived) framework of the Lausanne-based Centre International d'Etudes sur le Fascisme (CINEF) or 'Fascist International', ${ }^{36}$ through active proselytisation by fascists or their sympathisers, or through particular contacts such as an emergent band of Hindu-Aryan chauvinists seeking out the Italian Fascists in the 1920 s to train and influence its own paramilitary wing, the Rashtriya Swayamsevak Sangh (Rss), for organised violence. ${ }^{37}$ The family of ideas that coalesced into fascism at the conjunctural moment of the

32 For a recent critical account of Romanian fascist circles, see Cristina Bejan, Intellectuals and Fascism in Interwar Romania: The Criterion Association (New York: Palgrave Macmillan, 2019), at least one of whose central figures, Mircea Eliade, was a prominent scholar of religions specialising on India, and now has an important Chicago professorship named after him.

33 See for instance Arnd Bauerkämper and Grzegorz Rossoliński-Liebe, eds., Fascism without Borders: Transnational Connections and Cooperation between Movements and Regimes in Europe from 1918 to 1945 (New York: Berghahn, 2019) —which still restricts itself to Europe.

34 See for instance Federico Finchelstein, Transatlantic Fascism: Ideology, Violence, and the Sacred in Argentina and Italy, 1919-1945 (Durham: Duke University Press, 2010).

35 See Benjamin Zachariah, 'Indian Political Activities in Germany, 1914-1945', in Transcultural Encounters between Germany and India: Kindred Spirits in the Nineteenth and Twentieth Centuries, eds. Joanne Miyang Cho, Eric Kurlander and Douglas T. McGetchin (New York: Routledge, 2014), 141-154.

36 David Bradshaw and James Smith, 'Ezra Pound, James Strachey Barnes ('The Italian Lord Haw-Haw') and Italian Fascism,' Review of English Studies New Series, 64, no. 266 (2013): 672-693; Thomas Linehan, British Fascism 1918-1939: Parties, Ideology and Culture (Manchester: Manchester University Press, 2000), 128-131; Major J.S. Barnes, The Universal Aspects of Fascism (London, 1928); Major J.S. Barnes, Fascism, 2nd edition (The Home University Library of Modern Knowledge: London: Thornton Butterworth Ltd, 1934).

37 Marzia Casolari, 'Hindutva's Foreign Tie-Up in the 193os: Archival Evidence,' Economic \& Political Weekly, 22 January 2002, 218-228; Marzia Casolari, In the Shadow of the Swastika: The Relationships between Indian Radical Nationalism, Italian Fascism and Nazism (London: Routledge, 2020). 
1920 s had been around for some time, at least since the latter part of the nineteenth century, ${ }^{38}$ and contemporary observers in the heyday of fascism had already been able to point out that the division of human beings into Herrenvolk and Untermenschen (or equivalent hierarchical ideas) had not needed the Italian Fascists or the German National Socialists: in India, for instance, ideas of caste, duty and destiny had been adequate to this task, ${ }^{39}$ mapped onto ideas of a hierarchy and evolution of races provided by the Theosophists, who were as much a late imperial Russian as an American or Indian phenomenon. ${ }^{40}$

My approach conceives of fascism as a family of ideas, with commonthough often disavowed-roots, intellectual underpinnings, styles and organisations of movements, and sometimes even a strong overlap of personnel. Fascists and pre-or proto-fascists (the latter terms being less useful or necessary if we think in terms of a continuum) shared world views and ideas in an oftendisavowed communication that took place across regional and national boundaries, somewhat awkwardly, given that fascists claimed the unique genius of their particular nation. They shared much common ground in terms of romantic irrationalism, the concept of the intrinsic inequality of human beings of different types, or the transcendental nature of violence.

The emergence of a fascist imaginary and a fascist set of political organisations in the 1920 s and 1930s depended to a large extent on what I call a 'voluntary Gleichschaltung' of ideas, movements, and institutions, which, whether emerging in parallel or in self-conscious acknowledgement of each other's existence, recognized one another as belonging to the same family, and adopted some of the characteristics of a more successful sibling, in the process beginning to resemble one another more than they had at the time of mutual recognition. ${ }^{41} \mathrm{~A}$ number of these ideas existed in earlier versions from the previous century, and they lent themselves to a fascist repertoire that found its conjuncture between the two world wars, with the entire repertoire seldom mobilised at once. ${ }^{42}$

38 Zeev Sternhell, 'How to Think about Fascism and Its Ideology,' Constellations 15, no. 3 (2008): 280-29o.

39 M.N. Roy, Fascism (Calcutta: DM Library, 1938), 12-13.

40 See for instance Nicholas Goodrick-Clarke, The Occult Roots of Nazism: Secret Aryan Cults and their Influence on Nazi Ideology (New York: New York University Press, 1992), and Eric Kurlander, 'The Orientalist Roots of National Socialism? Nazism, Occultism, and South Asian Spirituality, 1919-1945,' in Transcultural Encounters between Germany and India: Kindred Spirits in the Nineteenth and Twentieth Centuries, eds. Joanne Miyang Cho, Eric Kurlander and Douglas T. McGetchin (New York: Routledge, 2014), 155-169. 
Discredited in terms of its movements and language of legitimation at the end of the Second World War, fascism had to rebuild on the basis of a new language that avoided the delegitimised vocabulary of its defeated past, in effect finding new ways to say and to justify old things - until such time as it would be safe to return to that older language or a variant thereof in a new era. But in certain countries and areas, fascisms had never been discredited, since they were not recognized as fascism.

\section{Caroline Campbell, Associate Professor of History, University of North Dakota, USA}

What does it mean to 'decolonise' fascist studies? In the United States, decolonising institutions (including academic disciplines) often refers to recognizing and dismantling the racist, classist, sexist, ableist, and heteronormative structures upon which such institutions were created and continue to operate. In this context, is the question of decolonising fascist studies a methodological one? If so, it might take place in the topics scholars study, sources they use, and theories and concepts that inform their inquiries. For example, while scholars have long debated the relationship between colonialism and Nazism in Germany, the case of France lacks a similarly deep inquiry into colonialism and fascism even though France had the second largest empire in the world in the 1930s and had engaged in colonial conquest since the sixteenth century. The radical right was also exceptionally strong in France in the 1930s, culminating in the Vichy regime and France's complicity in the Holocaust. However, these facts have yet to shape studies of French fascism and how the French case compares more broadly.

Some would argue that decolonising an academic field must go deeper than methodology if it is to truly grapple with dismantling the oppressive structures upon which it was built. In the case of fascist studies, the oppressive structures are still with us, reflected in issues of demographics and subjects of study. For example, even though Fascism: Journal of Comparative Fascist Studies and its association, the International Association for Comparative Fascist Studies (COMFAs) are less than ten years old, they lack the demographic diversity of other disciplines (which in themselves are too often dominated by white men). Since its inception in 2012, Fascism has published ninety articles; only fourteen

see for example Roger Griffin, 'General Introduction,' in Fascism, ed. Roger Griffin (Oxford: Oxford University Press, 1995), 1-12; Roger Griffin, The Nature of Fascism (London: Pinter, 1991); Roger Eatwell, Fascism: A History (London: Vintage, 1996). 
are written by women ( 16 per cent) and no more than a couple from a person of colour (to use a phrase common in the United States). While fascism is a global phenomenon there was only one article on fascism outside of Europe (on Japan) until a special issue in 2018 included articles on Argentina and Indonesia. Another special issue in 2020 on global cultures of anti-fascism included China and Australia. Moreover, while Fascism is increasingly including nonEuropean fascisms, the lack of studies on women and gender is striking. Less than five articles explore women and gender in depth, which has the detrimental result of casting fascism as an all-male and genderless phenomenon.

For fascist studies to decolonise, it must shift from being the purview of white men to one that provides a sense of belonging to groups that are historically underrepresented (women and people of colour). An example of what this might look like is the recent so-called 'German Catechism Debate' spearheaded by Jennifer Evans and the New Fascism Syllabus in 2021. ${ }^{43}$ Nineteen contributors trained in German history, the history of empire, Black Studies, gender studies, and critical theory all discussed the ways in which memories of the Holocaust have shaped German political culture. Thirty-two per cent of the contributors were women and several were scholars of colour who, informed by methods specific to their fields of study, debated such weighty issues as the uniqueness of the Holocaust. One of the most important points that the debate raised was that while Germans are willing to grapple with their responsibility for the Holocaust, they ignore the genocidal violence that Germany committed in the colonies. While comparing the Holocaust and colonial genocides is generally accepted by scholars, the broader public (including powerful politicians) recoil against it with such vehemence that A. Dirk Moses argues that it constitutes a 'heresy'. Although controversial, the 'Catechism Debate' reveals how academic debates that are shaped by diverse scholars and the subjects they study can challenge a broader political culture to reexamine its fundamental assumptions.

Other institutions are more overt in their efforts to decolonise. In response to publishing a racist book review, the top historical journal in the United States, the American Historical Review, announced in 2018 that it would begin 'decolonizing the $A H R^{\prime}$ and established a series of new policies to do so. ${ }^{44}$ In the context of French studies, after an email thread that included racist comments, H-France issued a statement of 'Common Understanding' that recognized the

43 Jennifer Evans, ed., 'The Catechism Debate,' The New Fascism Syllabus: Exploring the New Right through Scholarship and Civic Engagement, August 20, 2021, http://newfascism syllabus.com/category/opinions/the-catechism-debate/, accessed August 26, 2021.

'Decolonizing the AHR,' American Historical Review 123, no. 1 (2018): xiv-xvii. 
'White and male supremacy, cis-heteronormativity, ableism, and classism' that marginalized certain groups and topics in the field. To address these problems, H-France created an Equity, Diversity, and Inclusion committee whose guiding principles reflect the decolonisation goals of the $A H R \cdot{ }^{45}$ Likewise, amidst the rise of the global antiracist movement, the Western Society for French History (WSFH) created the 'WSFH engagé.e.s.' as a 'lasting structure' to integrate antiracism into all WSFH activities. Its mission focuses on 'combatting structural inequalities as well as all forms of oppression and discrimination in our field and beyond. ${ }^{46}$ These are potential models that fascist studies could adopt if its practitioners sought to dismantle the oppressive structures that have shaped the field, and in doing so, maintain its relevancy.

45 'H-France Common Understanding,' H-France.net, https://h-france.net/h-france-common -understanding/, accessed August 26, 2021.

46 Western Society for French History, 'wsFH engagé.e.s,' wsfh.org, https://www.wsfh.org/ wsfh-engages, accessed August 26, 2021. 